\title{
Issues of Technical Support for e-Learning Systems in Higher Education Institutions
}

\author{
Dr. Allah Nawaz \\ Department of Public Administration, Gomal University, Pakistan \\ profallahnawaz@gmail.com \\ Muhammad Zubair Khan \\ Department of Political Science, Gomal University, Pakistan \\ zubairbaluch@gmail.com
}

\begin{abstract}
Information and communication technologies (ICTs) have provided several tools to facilitate higher education. However, their effective use demands technical expertise to achieve the required academic goals. The university constituents (teachers, students and administrators) are given eTraining but this is not enough. Every eLearning system establishes a basic 'infrastructure' of computers, networks, communications and a technical department filled with ICT professionals to consistently maintain and upgrade the infrastructure, train the users and continuously provide technical support as and when required by them. Given the non-stop nature of technical support for eLearning, HEIs are facing issues in creating robust infrastructural facilities that are both competitive with the external environment and compatible with the internal user requirements. This article is a compendium of the touchy aspects in sustained technical support for eLearning in HEIs.
\end{abstract}

Index Terms- ICTs, ETS, ePedagogy, eLearning, eReadiness.

\section{INTRODUCTION}

Given the global availability of educational technologies (ETS), research tells that instructional technologies provide a platform of opportunities for all the higher education institutions (HEIs) in the world [1] and these are more gainful for the developing states to solve their long-standing education problems. Online education is helping these countries to access masses for education, which has not been possible through providing physical education facilities at that large scale [2]. Similarly, information and communication technologies (ICTs) are helping less advanced countries to reduce their sense of isolation in the world by connecting the world community online through internet facilities to learn, enjoy and do business and politics [3][4].

It should however be noted that the success of the eLearning projects is dependent on the skills and quality of technical support available to users [5]. Without proper technology support and maintenance of even the most current and sophisticated hardware and software, the ability of teachers and students to use technology is obviously compromised [6]. Furthermore, there is communication and knowledge-gap between developers and users in adopting the new systems [7]. In a study of four institutions, the successful development of online programs was attributed to providing adequate levels of pedagogical guidance and technical support [8][9].

The need for assistance and support in using technology is very important in the beginning of studies therefore, it is imperative to create an environment which helps students to learn how to learn [10]. However, ETS does not start working just as purchased by the users or organizations rather they have to be harnessed and tamed [11] in accordance with the requirements of the user and organization. There is along array of such technologies and all are not good for every institution rather there has to be a rational selection of relevant hardware, software and networking services [12][13].

Furthermore, there is the problem of 'leading-edgesyndrome' around the world [1]. It refers to the purchase of cutting-edge technologies for eLearning projects. Although research tells that 'tested technologies' are better than the new and untested options; most of the institutions are opting for these technologies. The research reveals that mostly leading-edge systems turn into bleeding-edge systems with over-costs, learning problems and issues of their integration with the existing systems [7], however, this is a big problem for the advanced countries [4].

The biggest technological issue for the countries like Pakistan is the creation of country wide digital infrastructure, facilities and services at every HEI level [14][15]. At the institutional level, the widely reported technological problems relate to the existence and support of technical unit in the institute. Users need continuous and timely help from the technical department, which is reportedly mostly unavailable [16]. Thus, dependence on technical section and staff is a big issue for the eLearning users [17].

After introduction, a discussion of educational technologies in higher education has been given to portray the role of ICT for teachers and students followed by a debate over the leading issues of technical support. The paper then presents the prospects of the issue and ends with conclusions extracted from the discussion.

\section{EDUCATIONAL TECHNOLOGIES IN HIGHER EDUCATION}

As a major consumer of software applications and web services, educators should take interest in learning about 
the usability of these technologies [18]. High-quality digital literacy requires the administration to provide support for faculty by adequately funding the IT services to accommodate the demands placed upon them [19]. IT is currently used effectively in libraries, research and development, as a communication medium, and for teaching and learning. Internet is making a unique contribution to these processes and providing services to the students at diverse locations [17].

At the broader level, an eLearning solution for any HEI consists of three elements: Content, Technology and Services.

\section{A. Content}

In eLearning, new forms of educational contents (radio programs, Web-based courses, multimedia on CDs or DVDs, etc.) are developed, existing contents are adapted and print-based contents are converted into digital media [1]. Beside the classroom and published content the eLearning education and learning content (courses, events, resources, mentoring, etc.) is gaining momentum in the eLearning solutions. The purpose of eLearning contents is to interactively serve the learners with different backgrounds [20]. In eLearning, the contents are delivered through Internet, intranet, extranet, satellite TV, CDs, virtual classrooms and digital collaboration [21][13]

\section{B. Technology}

Technology comprises of infrastructure, learning content management systems (LCMS), and learning management systems (LMS). 'Infrastructure' here refers to Internet, Intranet or hybrid delivery platforms, facilities for offline and remote access, user interfaces and personalization and customization capabilities. LCMS refers to management of learning offerings options for delivery, tracking, management and reporting of online content. LMS refers to capabilities for skills dictionaries, competency definition and mapping, performance management, employee development plans, financial and activity tracking/reporting, integration with other systems. Learning technologies are characterized for facilities like mentoring, chatting and discussion forums, Web seminars, online meeting and classroom sessions [22][23][19].

\section{Services}

Services include:

1. Consultancy, which refers to strategy and design of the eLearning program.

2. Support or assistance with implementation of the eLearning program. Support is required for launching, marketing and promotion of eLearning programs. It is imperative for establishing and managing technology platforms and infrastructure. Assistance is also required for the management of feedback and its reporting.

3. Design and build services which refer to building custom contents for specific education, transferring existing materials to online format, tailoring and customization of the eLearning platform and delivery environment, and integration with other applications [20].

\section{THE ROLE OF TECHNICAL SUPPORT FOR E- LEARNING}

Technical support is indispensable both for the teachers and students [10]. For teachers, technical support is needed to ensure that teacher has the resources and skills necessary for technology-integration into the class practices. For students, technical support helps in the acquisition of knowledge and skills necessary to fulfill their unique curriculum requirements [6]. Technical support includes "installation, operation, maintenance, network administration and security" [3]. The ICT support covers resolving hardware problems, implementing software installations and helping users in common applications of ICTs in eTeaching, eLearning and eEducation [24][4].

Technological sustainability involves choosing technology that will be effective over the long term [1]. Gray et al., [5] reported, after studying a group of universities running successful eLearning projects that "the success of the project was often dependent on the skills and quality of technical support provided to endusers." Likewise, researchers suggest that the university constituents "need to get technical and human resource support for continuous technology integration after the training" [25]. This support includes the technicalinfrastructure manned with technical talent such as network managers, web administrators, security specialists etc., but universities are facing challenges in preparing IT-workers for new digital environments [8].

Despite help from the IT centre most problems need to be solved at teachers or students level. The student survival in the digital age seems to depend on how well one knows people who can help with different problems [10]. Because, support to eLearning does not simply refer to bridging the hardware-divide rather it should help users in getting knowledge, skills, and consistent support of organizational structures to achieve broader social and community objectives [26][27]. Technical support is an important part of the implementation and integration of ICT in education however often it is not available requiring the teachers and students to command some basic troubleshooting skills [17].

\section{A. Infrastructure \& Facilities}

A strategic plan for educational technology includes the technological infrastructure and the roadmap according to which new technologies will be adopted for teaching and learning [28]. Thus, it is necessary to establish an infrastructure, which is reliable and loaded with all facilities [29]. There is also need to invest in the central support like helpdesk, training, documentation, registration, authentication etc [30]. Because high-quality digital literacy requires the HEIs to provide support to the faculty by adequately funding the IT department and professionals so that they can accommodate the demands placed upon them [31] thereby showing eMaturity in using ICT tools and techniques [16].

In the digital age technology is changing fast. The result is that compatibility and flexibility to adapt to different devices and platforms are important issues in 
infrastructure [10] because reliability of equipment means that technical support staff can spend less time on maintenance and much more time for training teachers and students in the use of software [32]. Furthermore, the adoption and maintenance of educational technologies is also expensive. The capital cost of the entire infrastructure needed to initiate the process is quite obvious. A little less obvious is the high level of recurrent costs associated with the effective use of ICT [31][8].

\section{B. Technical Department \& Staff}

Technical support specialists are essential to the continued viability of ICT use in a given school. General competencies that are required for eLearning technical experts are installation, operation, and maintenance of technical equipment (including software), network administration, and network security. Without on-site technical support, much time and money may be lost due to technical breakdowns [1]. The success of an eLearning project is often dependent on the skills and quality of technical support provided to end-users [5] by "IT division” [33]. In the universities, eLearning environment requires technical staff like network managers, web administrators, e-commerce developers, and security specialists. The number of graduates in computer science and information systems is inadequate to meet worldwide demand of professionals [13].

Technical staff assists lecturers in preparing material, and they would also maintain and develop the system. They are also responsible for the high-level architecture of the environment [10]. The effectiveness of technology support staff is measured by the degree to which endusers detect their presence. In other words, when systems and resources operate seamlessly, users tend to take the supporting-staff for granted. In many cases, the only interaction users have with such staff occurs at times when technology gives problems [6]. The current teaching force needs to be better supported through provision of technology integration specialists who can support classroom technology integration via mentoring and/or team teaching [25][34].

\section{ISSUES FOR HEIS}

Getting computers into the classroom is relatively easy but keeping them working is a greater challenge [35] because developing and implementing a strategic plan that includes educational technology is often a difficult and complex process [28]. HEIs are also very preoccupied with the rate of technological change and its increasing cost over time [36]. In most of the developing countries there is insufficient technical support and services [24] and very limited number of technical experts are available [3]. Across the literature, certain issues surface over and over in all the surveys of HEIs in developed and developing countries such as, changing technologies, leading-edge syndrome, professional-user communication and users' digital literacy [37][24]. An information system is not just built and thereafter operates without any interruption rather research has unfolded several technology-centric attitudes, human problems, cultural conflicts, and political maneuvering in the success and failure of an information system [7].

\section{A. Changing Technologies}

In the digital age technology is changing fast therefore compatibility and flexibility to adapt to different devices and platforms are important issues in infrastructure [10]. Given the rapid changes in ICTs, this becomes indispensable for professionals to fight the "threat of technological obsolescence" [1]. Likewise, in a developing country, a list of problems (relating to electrical spikes, viruses, dust, heat, and normal wearand- tear) can bring "the computer labs to a screeching halt” [35]. Having said that, in developing countries HEIs have to be in the forefront of ensuring ICT revolution, but they are unable and ill-prepared to play such a leadership role because of having poorly developed infrastructure [3]. A system needs to be capable of being changed throughout its life [7][19][17].

\section{B. Leading-Edge syndrome}

Furthermore, while developing and/or updating, most of the HEIs opt for cutting-edge technologies however, experience shows that mostly these 'leading-edge technologies turn into bleeding-edge technologies' by eating up budgets and delivering nothing special. Therefore researchers suggest that "go with tried and tested systems" [1]. At the same time latest digital options are expensive while, "the time is right for collaborative action because the time is wrong for any approach other than cost-sensitive, resource-smart deployments"[37]. An effective technical support also means that users are not only trained in using technologies but continuously updated about the user and possibilities created by these gadgets [38][4][39].

\section{Users' digital-literacy}

The advocates of social inclusion through ICTs propose a focus on electronic literacy as a key to overcoming the digital divide [26]. Different groups of people: students, teachers, and employers--have different ideas about what computer literacy means and during the last 25 years, several models and approaches of computer and information literacy have started to merge [31]. Now, digital literacy skills are considered necessary for effective and mindful learning in the emerging digital environments [40]. People acquire their technology literacy in two ways: formally through school programs or in the workplace, and informally, whether at home, from friends, or by themselves [41].

The implementation of ICT can also be interpreted as redesign of an infrastructure with significant impact on both the work of the individual teacher and his or her surroundings [42]. The emergence of Web services technologies enhances the possibility of bringing divergent participants together; these technologies make the ad-hoc integration of data and computer applications invisible to users so that they can enjoy a more userspecific experience [43]. In this environment and in order to perform new teaching functions, the teachers' "eTraining" should focus on the development of specific 
abilities and skills: 1 Professional: knowing the material, the contents, activities, didactic methods and teaching plan, etc; 2 Technical: although it is not necessary for them to be as expert as the support personnel, they should have basic skills which allow them to carry out their function appropriately, etc; and 3 Personal: interacting, giving feedback, receptive capacity, initiative, creativity, empathy etc. [44][39].

\section{PROSPECTS}

Without proper support and maintenance of even the most current and sophisticated hardware and software, the ability of teachers and students to access and use technology is severely compromised [6]. The degree of dependence on technical support is defined and determined by the degree of users' digital literacy. Research shows that pragmatically, there is too much dependence of eLearning users on the support and services of technical help-desk and which is sometimes frustrating for the teachers and students therefore the issue has to be resolved both at the users IT department/professional levels. "University constituents: teachers, students \& staff" [33] or "campus constituents" [45] have to be trained again and again to become selfsufficient in handling the digital devices. Furthermore, if technical section and professionals are well-prepared, there will be least complaints from users and thus, reduced calls for help. If the infrastructures are skillfully maintained, the problems are less likely to occur [46]. However, given the issues of user-training and weaknesses in infrastructure, technical department services and professionals, dependence of users on developers is proving a big issue [39].

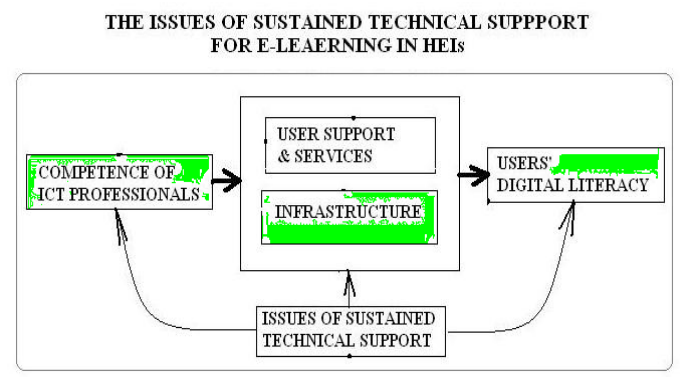

Figure 5.1 Technical Support \& Issues of eLearning in HEIs

Furthermore, although the prices of computers are falling and the developing countries are finding a variety of technologies with low budgets however, new and advanced technologies and their availability in abundance requires a lot of finances. At the same time, governments are reducing the funding of public universities therefore affording an expensive eLearning infrastructure is becoming an uphill task for the HEIs in public sector. To resolve this issue, Carey \& Gleason [45] argue that since it is not possible for the individual universities to duplicate leading edge technologies at every institute level, therefore, universities are relying on third-party solutions to meet student demands more economically and on a level that cannot be duplicated by an individual institution. Thus, outsourcing is the collaboration with the outsiders who are specialized in a particular eLearning technology or service [41] for example:

\section{A. Applications}

It is imperative for HEIs to control costs, reduce the burden on their technical staff, and provide improved services. Enterprise resource planning (ERP) and campus management systems (CMS) applications and more importantly, the existence of free and open source systems (FOSS), an open architecture - all can enable partial outsourcing of the application-base, and HEIs will easily be able to switch from one third-party service provider to another if they are dissatisfied with the services.

\section{B. Integration-services}

Another issue for HEIs in adopting eLearning is the integration or interfaces of a multitude of software applications. This integration layer can be outsourced to a third-party service provider. The interfaces within and outside the institutions must conform to the higher education industry standards for messaging, security and privacy.

\section{Outsourcing the processing layer}

Every HEI generally performs the same administrative functions and similar processes to support those functions. This work can be outsourced easily and cheaply to an agency that performs the same tasks for multiple institutions.

Effective technology support is concerned with planning, development, and maintenance of technology systems and resources; providing immediate support for the use of those systems on an as-needed basis; and enhancing teacher and student competency in technology integration through long-term development courses and programs [6]. So far most of the HEIs in developing countries have basic ICT infrastructure such as Local Area Network (LAN), internet, computers, video, audio, CDs and DVDs, and mobile technology facilities that form the basis for the establishment of e-learning [3]. Normally it is expected that as the institute builds up its infrastructure over the years and the faculty gains experience the pedagogy followed shifts from pure lecture method to instructional technology [47].

There is also great uncertainty among decision-makers and managers as well as among developers, trainers and learners: instructors find themselves confronted with a new role in which they are tutors and facilitators for learning processes [48]. Technology training alone cannot necessarily ensure that these teachers would infuse technology into their routine instruction and a radical change in their instructional practices would occur. However, they need to get technical and human resource support for continuous technology integration after the training [25]. Given the premise that IS development is a learning process, it requires an open environment wherein all the participants have the opportunity to make sense of the new technological work environment [7][8]. 


\section{CONCLUSIONS}

From the above review and discussions several conclusions can be drawn regarding the contemporary conditions of technical issues for eLearning in higher education as well as the prospects of this problem. It is true that current state of affairs $s$ the predictor of the future but if constructive interventions are undertaken, the issues of technical support can turn into opportunities. This technical support is needed to address not only the hardware and software complaints but more importantly help-out the users at times when they are stuck in the system or program - and this is recurring.

Given the fact that networks need more frequent and instant attention 24/7 than the stand-alone systems, there is no other option for HEIs but to establish a sustainable technical support with due consideration for the requirements of system and users. The investments in strengthening technical support are actually infusing robustness in the functioning of the eLearning systems and users. Furthermore, security issues are also demanding the alertness of the technical assistance so that the threats to the system could be handled in a timely and compatible manner.

\section{REFERENCES}

[1] L.V. Tinio. ICT in education. Presented by UNDP for the benefit of participants to the World Summit on the Information Society. UNDP's regional project, the Asia-Pacific Development Information Program (APDIP), in association with the secretariat of the Association of Southeast Asian Nations (ASEAN). 2002. Retrieved April 10, 2011, from http://www.apdip.net/publications/ iespprimers/eprimer-edu.pdf.

[2] J. Hvorecký., V.S. Manažmentu., \& P. Cesta. "Can E-learning break the Digital Divide?” European Journal of Open, Distance and E-Learning, 2005. Retrieved September 27, 2011, from http://www.eurodl.org/.

[3] A.S. Sife., E.T. Lwoga., \& C. Sanga. "New technologies for teaching and learning: Challenges for higher learning institutions in developing countries." International Journal of Education and Development using ICT, 3(1), 2007. Retrieved September 27, 2011, from http://ijedict.dec.uwi.edu//.

[4] A. Nawaz. "Using eLearning as a tool for 'education for all' in developing states." International Journal of Science and Technology Education Research (IJSTER), 1(6), 2010.

[5] D.E. Gray., M. Ryan., \& A. Coulon. "The Training of Teachers and Trainers: Innovative Practices, Skills and Competencies in the use of eLearning." European Journal of Open, Distance and ELearning, 2003. Retrieved August 9, 2011, from http://www.eurodl.org/.
[6] G. Valdez., K. Fulton., A. Glenn., N.A. Wimmer., \& R. Blomeyer. "Effective Technology Integration in Teacher Education: A Comparative Study of Six Programs.” Innovate Journal of Online Education, 1(1), 2004. Retrieved April 10, 2011, from http://Innovateonline.info.

[7] A. Nawaz., G.M. Kundi., \& B.D. Shah. "Metaphorical interpretations of information systems failure.” Peshawar University Teachers' Association Journal, 14, 15-26, 2007.

[8] Q.A. Qureshi., S. Ahmad., Najibullah., A. Nawaz., \& B. Shah. "eLearning development in HEIs: Uncomfortable and comfortable zones for developing countries.” Gomal University Journal of Research (GUJR), 25(2), 47-56, 2009.

[9] A. Nawaz., \& Q.A. Qureshi. "E-Teaching/EPedagogy: Threats \& Opportunities for teachers in HEIs.” Global Journal of Management \& Business Research (GJMBR), 10(9):23-31, 2010b.

[10] S. Sirkemaa. "Information technology in developing a meta-learning environment.” European Journal of Open, Distance and E-Learning, 2001. Retrieved August 9, 2011, from http://www.eurodl.org/.

[11] R. Stephenson. "Open Source/Open Course: Learning Lessons for Educators from Free and Open Source Software.” Innovate Journal of Online Education, 3(1), Oct/Nov. 2006. Retrieved April 10, 2011, from http://Innovateonline.info.

[12] T. Nyvang. "Implementation of ICT in Higher Education as Interacting Activity Systems.” 2006. Retrieved April 10, 2011, from http://www.networked learningconference.org.uk/abstracts/pdfs/P27\%20N yvang.pdf

[13] A. Nawaz. \& G.M. Kundi. "Digital literacy: An analysis of the contemporary paradigms.” Journal of Science and Technology Education Research (JSTER), 1(2):19-29, 2010b.

[14] ADB. "Sector Assistance Program Evaluation for the Social Sectors in Pakistan SAP:PAK." July, 2005. Operations Evaluation Department. Asian Development Bank. Retrieved September 27, 2011, from http://www.adb.org/ Evaluation/ methods.asp.

[15] T. Hameed. "ICT as an enabler of socio-economic development.” 2007. Retrieved September 27, 2011, from http://www.itu.int/osg/spu/digitalbridges/ materials/hameed-paper.pdf.

[16] H.B. Moolman., \& S. Blignaut. "Get set! eReady, ... e-Learn! The e-Readiness of Warehouse Workers.” Journal of Educational. Technology \& Society, 11 (1), 168-182, 2008. Retrieved April 10, 2011 from http://www.ask4research.info/.

[17] A. Nawaz., Z. Awan., \& B. Ahmad. “Integrating educational technologies in higher education of the 
developing countries." Journal of Education and Practice, 2(2), 2011.

[18] J. Buzhardt., \& L. Heitzman-Powell. “Stop blaming the teachers: The role of usability testing in bridging the gap between educators and technology." Electronic Journal for the Integration of Technology in Education, 4, 13, 2005. Retrieved September 27, 2011, from http://ejite.isu.edu/Volume3No1/.

[19] A. Nawaz., \& Q.A. Qureshi. "Sustained technical support: Issues \& prospects for eLearning in HEIs.” Global Journal of Management \& Business Research (GJMBR), 10(9):32-39, 2010a.

[20] D. Dinevski., \& D.P. Kokol. "ICT and Lifelong Learning." European Journal of Open, Distance and E-Learning, 2005. Retrieved September 27, 2011, from http://www.eurodl.org/.

[21] N. Manochehr. "The influence of learning styles on learners in E-Learning Environments: An empirical study.” Computers in Higher Education and Economics Review, 18, 2007. Retrieved April 10, 2011 from http"//www.economicsnetwork.ac.uk/cheer.htm.

[22] C. Dalsgaard. "Social Software: E-learning beyond learning management systems.” European Journal of Open, Distance and E-Learning, 2006. Retrieved August 09, 2011, from http://www.eurodl.org/.

[23] K. Barnes., R.C. Marateo., \& S.P. Ferris. “Teaching and learning with net generation.” Innovate Journal of Online Education. 3(4): 2007. Retrieved August 09, 2011, from http://innovateonline.info.

[24] S.A. Mokhtar., R.A. Alias., \& A. Abdul-Rahman. "Academic computing at Malaysian colleges." International Journal of Education and Development using ICT, 3(2): 2007. Retrieved September 27, 2011, from http:ijedict.dec.uwi.edu//.

[25] Y. Zhao., \& F.B. LeAnna. "Can teacher technology integration training alone lead to high levels of technology integration? A qualitative look at teachers' technology integration after sate mandate technology training." Electronic Journal for the Integration of Technology in Education, 5, 53-62. Retrieved April 10, 2011, from http://ejite.isu.edu/volume5No1/.

[26] H. Macleod. "What role can educational multimedia play in narrowing the digital divide?” International Journal of Education and Development using ICT. 1(4): 2005. Retrieved August 09, 2011, from http://ijedict.dec.uwi.edu//.

[27] P.J. Ågerfalk., G. Goldkuhl., B. Fitzgerald., \& L. Bannon. "Reflecting on action in language, organizations and information systems.” European Journal of Information Systems, 15: 4-8, 2006. Retrieved April 10, 20117, from http://www. palgrave-journals.com/ejis/.
[28] D. Stockley. "Strategic Planning for Technological Innovation in Canadian Post Secondary Education." Canadian Journal of Learning and Technology, 30(2), Spring, 2004. Retrieved September 27, 2011, from http://www.cjlt.ca/.

[29] T. Pfeffer. “Open sources for higher education. Do information technologies change the definition of public and private goods?" CHER 17th Annual Conference, Enschede, The Netherlands, 17-19 September 2004. Retrieved September 27, 2011, from http://www.iff.ac.at/hofo/pfeffer/2004_Pfeffer _open_sources_CHER.doc.

[30] M. Valcke. "ICT in higher education: An uncomfortable zone for institutes and their policies,” In R. Atkinson, C. McBeath, D. JonasDwyer \& R. Phillips (Eds), Beyond the comfort zone: Proceedings of the 21st ASCILITE Conference (pp. 20-35). Perth, 5-8 December, 2004. Retrieved August 9, 2011, from http://www.ascilite.org.au/conferences/perth04/proc s/valcke-keynote.html.

[31] Z. Ezziane. "Information Technology Literacy: Implications on Teaching and Learning." Journal of Educational Technology \& Society, 10 (3), 175-191, 2007. Retrieved April 10, 2011, from http://www.ask4research.info/.

[32] D. Lewis., \& R. Goodison. Enhancing learning with Information and Communication Technology (ICT) in Higher Education. Research Report RR533, Department for Education and Skills. (C) University of Wolverhampton, 2004, ISBN 1844782255. Retrieved April 10, 2011, from http://www.dfes.gov.uk/ research/data/uploadfiles/RR533.pdf.

[33] S. Juniu. "Digital Democracy in Higher Education Bridging the Digital Divide.” Innovate Journal of Online Education, 2(1), October/November, 2005. Retrieved August 9, 2011, from http://Innovateonline.info.

[34] A. Nawaz., \& G.M. Kundi. "Predictor of e-learning development and use practices in higher education institutions (HEIs) of NWFP, Pakistan.” Journal of Science and Technology Education Research (JSTER), 1(3):44-54, 2010a.

[35] R.J. Hawkins. “Ten Lessons for ICT and Education in the Developing World,” 2002. Retrieved April 10, 2011, from http://www.cid.harvard.edu/cr/pdf/ gitrr2002_ch04.pdf.

[36] B. Sasseville. "Integrating Information and Communication Technology in the Classroom: A Comparative Discourse Analysis." Canadian Journal of Learning and Technology, 30(2), Spring, 2004. Retrieved April 10, 2011, from http://www.cjlt.ca/.

[37] E. Klonoski. "Cost-Saving Collaboration: Purchasing and Deploying a Statewide Learning 
Management System.” Innovate Journal of Online Education, 1(4), April/May, 2005. Retrieved September 27, 2011, from http://Innovateonline.info.

[38] S. Kopyc. "Enhancing Teaching with Technology: Are We There Yet?” Innovate Journal of Online Education, 3(2), 2007. Retrieved April 10, 2011, from http://Innovateonline.info.

[39] A. Nawaz. "Users' training: The predictor of successful eLearning in HEIs.” Global Journal of Computer Science \& Technology (GJCST), 11(4):18, 2011.

[40] A. Aviram., \& Y. Eshet-Alkalai. “Towards a Theory of Digital Literacy: Three Scenarios for the Next Steps.” European Journal of Open, Distance and E-Learning, 2006. Retrieved September 27, 2011, from http://www.eurodl.org/.

[41] G.M. Kundi., \& A. Nawaz. "From objectivism to social constructivism: The impacts of information and communication technologies (ICTs) on higher education.” Journal of Science and Technology Education Research (JSTER), 1(2):30-36, 2010.

[42] T. Nyvang. Implementation of ICT in higher education: A case study of teachers implementing ICT into their teaching practice. 2003. Retrieved September 27, 2011, from http://www.intermedia.uib.no/cscl/doc/files/Nyvang .pdf.

[43] S. LaCour. "The future of integration, personalization, and ePortfolio technologies." Innovate Journal of Online Education, 1(4), April/May, 2005. Retrieved September 27, 2011, from http://Innovateonline.info.

[44] F.E. Blázquez., \& L.A. Díaz. “A Training Proposal for e-Learning Teachers.” European Journal of Open, Distance and E-Learning, 2006. Retrieved September 27, 2011, from http://www.eurodl.org/.

[45] P. Carey., \& B. Gleason. "Vision 2010: The Future of Higher Education Business and Learning Applications." Innovate Journal of Online Education, 3(1). Oct/Nov, 2006. Retrieved April 10, 2011, from http://Innovateonline.info.

[46] Q.A. Qureshi., A. Nawaz., \& Najeebullah. "Prediction of the problems, user-satisfaction and prospects of e-learning in HEIs of KPK, Pakistan.” International Journal of Science and Technology Education Research (IJSTER), 2(2):13-21, February, 2011. Retrieved April 15, 2011, from http://www.academicjournals.org/ijster/PDF/Pdf201 1/Feb/Qureshi\%20et\%20al.pdf

[47] A. Sattar., A. Nawaz., \& Najibullah. "Evolution of eLearning in HEIs: Challenges \& Opportunities for Developing Countries like Pakistan.” Journal of Emerging Trends in Economics and Management Sciences (JETEMS), 2011.
[48] U. Ehlers. "Quality in e-learning from a learner's perspective.” European Journal of Open, Distance and E-Learning, 2005. Retrieved August 9, 2011, from http://www.eurodl.org/.

\section{Dr. Allah Nawaz}

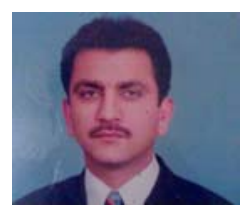

Dr. Allah Nawaz is Assistant Professor at the Department of Public Administration, Gomal University Pakistan. He completed his M.Phil from University of Leeds, U.K. He has done his Ph.D. in Management Information Systems from Gomal University Pakistan. His research interests include ICTs implications for Education, business and management. He has published more than fifty international journal articles.

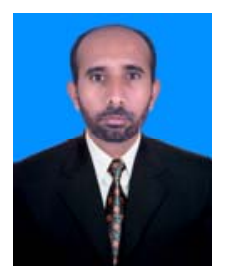

Mr. Muhammad Zubair Khan

Mr. Muhammad Zubair Khan is Lecturer at the Department of Political Science, Gomal University Pakistan. He completed his M.Phil. in Politics \& International Relations from International Islamic University Pakistan. He is currently pursuing his Ph.D. from the same university. His area of interest is socio-political implications of information and communication technologies. He has published five international journal articles. 